\title{
The Role of Financial Development in the Relationship Between Income Inequality and Economic Growth: Evidence from Method of Moments Quantile Regression
}

\author{
Muhammed Hanifi VAN1
}

\begin{abstract}
This study sheds light on the linear and nonlinear relationship between financial development level and income inequality across 79 countries within a period of 1995 to 2016. To test this relationship panel the Method of Moments Quantile Regression (MMQR), which was recently published by Machado and Silva (2019), has been employed. Besides Pedroni and GUV cointegration tests, FMOLS and DOLS have been administered. Although traditional mean estimators can explain the heterogonous nature of analysed countries, since their results depend on conditional mean they fall short in making the responses heterogonous. In that sense, the effects of specific factors such as financial and economic developments which also impact income inequality have been inspected via MMQR, which also takes into account certain econometric difficulties such as heterogeneity and endogeneity in various quantiles. Compared to other methods, another advantage of MMQR is that by providing information on how explanatory variables can influence the entire conditional distribution, it allows the use of methods only valid in the estimation of conditional means, such as difficulty in noticing heterogeneity and endogeneity problems in panel data models. According to the results obtained from the MMQR model, Greenwood and Jovanovic's (1990) inverted $U$ hypothesis was accepted only in countries with an inequality income distribution between financial development and income inequality, whereas in counties with equal income distribution the income inequality widening hypothesis was confirmed. According to Panel FMOLS and Panel DOLS and also coefficient estimations, Greenwood and Jovanovic (1990)'s inverted U hypothesis was confirmed in the relationship between financial development and income.
\end{abstract}

Keywords: Financial development, Income inequality, Kuznets Curve

Jel Codes: C33, D31, D63, 011, 015

\section{Gelir Eşitsizliği ve Ekonomik Büyüme Arasındaki İlişkide Finansal Gelişmenin Rolü: Moment Kantil Regresyon Yönteminden Bulgular}

Özet

Bu çalışma finansal gelişmişlik düzeyi ile gelir arasındaki doğrusal ve doğrusal olmayan ilişkiyi 79 ülkede 1995-2016 yılları arasında incelemektedir. Bu ilişkiyi test etmek için literatüre Machado ve Silva (2019) tarafindan tanıtılan panel Moment Kantil Regresyon Yöntemi (MMQR) ile Pedroni ve GUV eşbütünleşme testleri, FMOLS ve DOLS kullanılmıştır. Geleneksel ortalama tahmin ediciler, ele alınan ülkelerin heterojen doğasını açıklasalar da sonuçları koşullu ortalamaya dayalı olduğundan yanıtların heterojen olmasını sağlayamazlar. Bu amaçla, gelir eşitsizliğini etkileyen finansal ve ekonomik kalkınma gibi faktörlerin etkisi çeşitli kantillerde heterojenlik ve içsellik gibi ekonometrik zorlukları da dikkate alan MMQR yöntemi ile analiz edilmiştir. MMQR' in diğer yöntemlere göre avantajı ise, açıklayıcı değişkenlerin tüm koşullu dağılımı nasıl etkilediği bilgisini sağlayarak, panel veri modellerinde heterojenlik ve içsellik problemlerini dikkate alma zorluğu gibi sadece koşullu ortalamaların tahmininde geçerli olan metotları kullanmasına izin vermesidir. MMQR model sonuçlarına göre finansal kalkınma ile gelir eşitsizliği arasında yalnızca gelir dağılımı eşit olmayan ülkelerde Greenwood ve Jovanovic (1990)'in ters U hipotezi kabul edilmişken, eșit gelir dağılıma sahip ülkelerde ise gelir eşitsizliğini genişletici hipotez doğrulanmıştır. Panel FMOLS ve Panel DOLS ile katsayılar tahminlerine göre finansal gelişme ile gelir arasındaki ilişkide Greenwood ve Jovanovic (1990)'nin ters U hipotezini desteklemektedir.

Anahtar kelimeler: Finansal Gelişmişlik, Gelir Eşitsizşliği, Kuznet Eğrisi Jel Kodu: C33, D31, D63, 011, 015

ATIF ÖNERİ́i (APA): Van, M.H. (2021). The Role of Financial Development in the Relationship Between Income Inequality and Economic Growth: Evidence from Method of Moments Quantile Regression. İzmir İktisat Dergisi. 36(3). 725-737. Doi: 10.24988/ije.202136315

${ }^{1}$ Assist. Prof. Dr., Van Yüzüncü Yıl Üniversitesi, İktisadi ve İdari Bilimler Fakültesi, Tuşba / VAN,

EMAIL: hanifivan@yyu.edu.tr ORCID: 0000-0001-6093-011X 


\section{INTRODUCTION}

Although the relationship between financial development and income has been a frequent topic of research since the onset of the 19th century, no consensus has yet been reached on the topic. Regarding the concept of financial development and income inequality, there exists a comprehensive literature review conducted by Levine (2005) and DemirgüçKunt and Levine (2009).

Having examined income inequality within the very first theoretical framework, Kuznets (1955) reported that during the first stage of economic growth rural residents have a lower income than those living in urban areas, and yet it is a more equal income. In the subsequent stage of economic growth, as rural residents with lower income level migrate to the city, this inequality gap would initially widen more, but as migrants start to benefit from the advantages of urbanisation their income would also move up in due course; hence income inequality would go down. Kuznets explained this argument thus: inverted U-curve and economic growth would at first raise income inequality, but after a while inequality would be lowered. In the literature, three differences in the relationship between financial development and income inequality have been highlighted with hypotheses (Koçak and Uzay, 2019) which are nonlinear: inverted U hypothesis, negative linear hypothesis and positive linear hypothesis.

Based on the interlink between economic growth and income distribution as well as economic growth and financial structure, Greenwood and Jovanovic (1990) put forth the relationship between financial development and income distribution. Greenwood and Jovanovic suggested that to ensure the development of financial structure, growth would provide required resources while financial structure would ensure more efficient use of investments; hence a rapid growth could take place. According to this approach in the first stage that financial structures begin to develop, due to high costs originating from the substructure, only the rich class with a certain level of income could take advantage of market opportunities. Consequently, the income inequality gap between the rich and the poor would widen more. In the subsequent stage when financial markets can attain a definite volume by solving their substructure problems, the poor section would also attain the means for cheap credit and this process would result in a fall in the emergent income inequality in the market.

Galor and Zeira (1993) analysed the role of income distribution on the macro economy through human capital investment. In contrast to the inverted U-shaped nonlinear relationship, they detected that between financial development and income, there existed a negative linear relationship. Galor and Zeira argued that in the face of capital market defects, distribution of wealth significantly influenced total financial activity, and from the distribution of initial wealth, or more specifically individuals inheriting a wealth large enough to help them invest in human capital are more likely to invest in human capital. Since wealthy families possess greater savings they would bequeath more to their heirs, while poor families would leave no inheritance to their descendants. Lacking original wealth, poor families could utilise financial structures to invest, thereby lowering the income inequality gap. Similar to Galor and Zeira, Banerje and Newman (1993) also supported the narrowing hypothesis of income inequality between financial development and income inequality. Since poor people are deprived of capital and heritage it is hard for them to make an indivisible investment. They stated that by having original capital the rich are eligible to make indivisible investments, whereas the poor would mostly prefer to be employed in salaried jobs.

Banerje and Newman (1993) reported that in countries with underdeveloped financial markets income inequality would increase more since poor people would fail to meet their fund needs, but in line with the growth of 
financial markets the poor class would manage to access original capital and rise as entrepreneurs, and as a consequence income inequality would diminish (Topuz and Dağdemir, 2016).

\subsection{Motivation}

A different hypothesis suggests that financial development would expand income inequality (positive linearity), the widening hypothesis. This hypothesis puts forth that in countries with a weak financial structure, those wealthy and with good connections benefited more from the financial development compared to the poor, and as expected, financial development would fail to contract income inequality (Koçak and Uzay, 2019). Unlike rich people who can provide their assets as collateral in return for any purchased service, poor citizens would have no collateral to offer to financial intermediaries and as a consequence, they would not sufficiently benefit from the provided services. A poor group migrating to the city would have no budget to spare for human capital and education, hence making a new investment would turn into quite a challenge (Clarke et al., 2006). That being said, it is accepted that despite securing financial development, the rich class would benefit more from that achievement; thus income inequality would continue to escalate.

While examining financial development and income inequality, choosing the best econometric method is vital for the safety of empirical studies, and to achieve that Machado and Silva (2019)'s Method of Quantile Regression Moments (MMQR) was used in this research where analysed countries possess different income inequality distribution. By employing this method, the relationship of income inequality distribution with GDP and various control variables and income inequality in different quantiles can be presented. This approach, by providing insights on the way explanatory variables affect the entire conditional distribution, allows us to use methods valid only in the estimation of conditional means, such as difficulty in taking heterogeneity and endogeneity problems into account within panel data models.

\subsection{Contribution}

This current study offers two contributions to the existing literature. The first one is that, to the best of my knowledge, this study is the first to examine the relationship between economic and financial development and income inequality by employing the new "Method of Moments Quantile Regression" (MMQR) introduced by Machado and Silva (2019). Through MMQR, the effect of several factors such as economic and financial development on income inequality were analysed by also taking into account econometric difficulties such as heterogeneity and endogeneity in a range of quantiles. MMQR is distinguished from other quantile regression techniques because in this method, by employing fixed effects impacting the entire distribution, their effect on conditional distribution can be detected without changing the position of the independent variables' environmental performance (Alhassan et al., 2020). The second contribution is that related to the analysed countries, the relationship between financial development and income inequality and economic growth and income inequality was studied within the framework of the following hypotheses: Kuznets (1955), Greenwood and Jovanovic (1990), Banerje and Newman (1993), Galor and Zeira (1993).

\section{RELATED WORKS}

Many studies in the literature have shown that financial development would accelerate economic growth, whereas there is an ongoing dispute as to whether or not financial development would decrease poverty. Here the main problem is whether financial development has contributed to the whole community or prioritised the rich people, or whether financial development has offered a nonproportional advantage to the poor class (Beck et. al., 2004). The link between economic growth and income distribution was first analysed by Kuznets (1955). Particularly at the 
onset of the 1990s, these subjects were mostly analysed within a theoretical framework, but towards the end of the 1990s theoretical studies were replaced by empirical studies. The latter analysed the subject from two different scopes based on their research contexts. By employing panel data on the countries the effect of financial development on income inequality was examined by scholars such as Clarke et al. (2006), Shabaz and Islam (2011), Jauch and Watzka (2015), De Haan and Sturm (2017), Younsi and Bechtini (2018), Shin and Lee (2019). On the other hand, Shahbaz et. al. (2014), Nasreddine and Mensi (2016), Koçak and Uzay (2019), Bittencourt et al. (2019) analysed this relationship in their studies by focusing on a single country.

Liang (2008) studied the relationship between financial development and income inequality through the China case model. In his study from 1991 to 2000, Liang employed Generalised Method of Moment (GMM). By detecting a negative and linear relationship between financial development and income inequality the Greenwood-Jovanovic hypothesis was rejected and the narrowing hypothesis of income inequality was accepted.

Shahbaz and İslam (2011) examined the relationship between financial development and income inequality on the Pakistan case model, and they analysed the period between 1971-2015 by employing the ARDL limit test method. They concluded that although financial stability deteriorated, financial development decreased income inequality, thus they rejected the Greenwood-Jovanovic hypothesis and accepted the widening hypothesis in explaining income inequality.

Jauch and Watza (2016) analysed the relationship between financial development and income inequality among 138 developed and developing countries. This study, covering the period between 1960-2008, was analysed in an unstable panel model. Detecting that financial development escalated income inequality, they rejected the Greenwood-
Jovanovic hypothesis and accepted the widening hypothesis in explaining income inequality.

De Haan and Sturm (2017) examined the link of financial development, financial liberalisation and banking crises with income inequality across 121 countries. In their study, between 1975 and 2005, they analysed the period via the panel random-effects model and accepted the widening hypothesis in explaining income inequality.

Altunbaş and Thornton (2018) analysed the effect of financial development on income inequality across 121 countries from 1980 to 2015 by employing five-year mean figures and the quantile regression method. They concluded that in countries with equal income distribution, financial development increased income inequality, but in countries where income distribution is not equal, it diminished income inequality.

Younsi and Bechtini (2018) analysed the relationship between financial development and income inequality in the BRICS countries (Brazil, Russia, India, China and South Africa). They examined the period between 1995-2015 by employing panel cointegration, POLS and the GMM methods. The empirical findings they obtained confirmed Kuznets's hypothesis for the inverted U-shaped relationship among economic growth, financial sector development and income inequality across the BRICS countries throughout this decade.

\section{DATA AND METHODOLOGY}

\subsection{Data}

In this study effects of economic and financial development on income inequality have been tested.

The data are obtained from three sources, (i) Standardized World Income Inequality Database (2020), (ii) The World Development Indicators of the World Bank, (iii) Statistics Department of the International Monetary Fund. The data are shown in Table 1. 
Table 1: Definitions of Variables

\begin{tabular}{|c|c|c|c|}
\hline Data & Definition & Measurement Unit & Source \\
\hline Gini & $\begin{array}{l}\text { The annual growth rate of } \\
\text { Gini Index }\end{array}$ & $\begin{array}{l}\text { The gini coefficient is derived from } \\
\text { Lorenz Curve and range between } 0 \\
\text { (equality) and } 100 \text { (inequality) }\end{array}$ & SWIID (2020) \\
\hline $\operatorname{lnGDP}$ & $\begin{array}{l}\text { The annual growth real } \\
\text { GDP per capita }\end{array}$ & $\begin{array}{l}\text { GDP per capita, PPP (constant } 2017 \\
\text { international \$) }\end{array}$ & $\begin{array}{l}\text { World } \\
\text { Development } \\
\text { Index } 2020\end{array}$ \\
\hline $\ln F D$ & $\begin{array}{l}\text { Financial Development } \\
\text { Index }\end{array}$ & FDI annually & $\begin{array}{l}\text { International } \\
\text { Monetary Found }\end{array}$ \\
\hline $\ln G C$ & $\begin{array}{l}\text { General government final } \\
\text { consumption expenditure } \\
\text { includes all government } \\
\text { current expenditures for } \\
\text { purchases of goods and } \\
\text { services. }\end{array}$ & 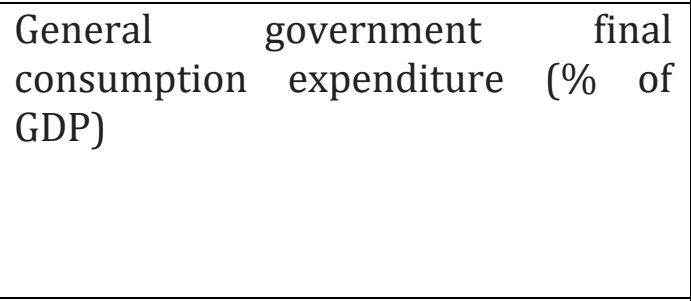 & $\begin{array}{l}\text { World } \\
\text { Development } \\
\text { Index } 2020\end{array}$ \\
\hline INF & Inflation & $\begin{array}{l}\text { Inflation as measured by the annual } \\
\text { growth rate of the GDP implicit } \\
\text { deflator shows the rate of price } \\
\text { change in the economy as a whole. }\end{array}$ & $\begin{array}{l}\text { World } \\
\text { Development } \\
\text { Index } 2020\end{array}$ \\
\hline
\end{tabular}

*In denotes natural logarithm.

\subsection{The Models}

Several models that can test the relationship between financial and economic development and income inequality will be demonstrated below. Kuznets (1955) hypothesis, Greenwood and Jovanovic's (1990) nonlinear hypothesis, Galor and Zeira (1993), Banerjee and Newman's (1993) linear hypothesis were tested via the regression model below,

$$
\begin{aligned}
\text { Gini }_{i t}=\beta_{0}+ & \beta_{1} F D_{i t}+\beta_{2} F D_{i t}^{2}+\beta_{3} \ln G D P_{i t} \\
& +\beta_{4} \ln G D P_{i t}^{2}+\beta_{5} \ln G C_{i t} \\
& +\beta_{6} I N F+\varepsilon_{i t}
\end{aligned}
$$

where Gini stands for the Gini coefficient; FD stands for financial development; lnGDP stands for real GDP's logarithmic value per person; lnGC stands for the logarithmic value of government expenditures and INF stands for annual inflation.

In the equation above, if $\beta_{1}>0$ ve $\beta_{2}<0$ then Greenwood and Jovanovic's (1990) nonlinear hypothesis is accepted, but if $\beta_{1}<0$ ve $\beta_{2}=0$ then Galor and Zeira (1993) and Banerjee and Newman's (1993) linear hypothesis is accepted. To test Kuznets' hypothesis GDP and GDP2 variables were included in the model. If $\beta_{3}>0$ ve $\beta_{4}<0$ the Kuznets (1955) hypothesis is accepted (Nasreddine and Mensi, 2016).

Table 2: Corelation Coefficients

\begin{tabular}{|l|l|l|l|l|l|l|l|}
\hline & Gini & FD & FD $^{\mathbf{2}}$ & lnGDP & lnGDP $^{2}$ & InGC $^{\text {INF }}$ \\
\hline Gini & 1.000 & & & & & & \\
\hline FD & -0.449 & 1.000 & & & & & \\
\hline FD $^{2}$ & -0.432 & 0.971 & 1.000 & & & & \\
\hline InGDP & -0.558 & 0.808 & 0.729 & 1.000 & & & \\
\hline InGDP & -0.572 & 0.828 & 0.756 & 0.998 & 1.000 & & \\
\hline InGC & -0.406 & 0.386 & 0.350 & 0.495 & 0.500 & 1.000 & \\
\hline INF & 0.001 & -0.180 & -0.159 & -0.159 & -0.164 & -0.057 & 1.000 \\
\hline
\end{tabular}


Table 2 demonstrates the correlation coefficients used in the model. Correlation coefficients between the analysed variables were found to be comparatively low.

\subsection{Panel Estimation Techniques}

In an attempt to obtain comparable estimators, three panel estimation techniques were employed for the heterogeneous panel, namely Dynamic Least Squares (DOLS), Fully Modified Least Squares, and Method of Moments Quantile Regression (MMQR). Panel sectional dependency was tested via Peseran (2004) CD test. In Table 3, aside from government expenditures (GC), it is detected that for the variables of financial development (FD), GDP and inflation, there exists a sectional dependency among countries.

To check whether the analysed variables manifested integration feature Im, Pesaran and Shin (IPS) (2003), Breitung and Das (2005) panel unit root tests were employed. Breitung and Das (2005) panel unit root tests suggested a common autoregressive parameter for all units within the panel, whereas the ImPesaran-Shin (IPS) (2003) test relaxes this assumption and instead it suggested that within each unit the test allowed the unit to have its own autoregressive parameter structure. According to Table 3, in both unit root tests, not all variables are stationary in level, but after taking the first difference, all variables I (1) become stationary.

Table 3: Cross- Sectional dependences and unit root test (Paseran (2003)

\begin{tabular}{llllll}
\hline Variable & Gini & FD & GDP & INF & GC \\
\hline $\begin{array}{l}\text { Panel 1: Cros-Sectional } \\
\text { dependence Test }\end{array}$ & $118.84^{* *}$ & $124.67^{* * *}$ & $211.82^{* * *}$ & $215.62^{* * *}$ & 18.81 \\
Panel 2: Unit Root Test & -0.9869 & 3.5277 & 20.0228 & 20.4323 & -1.2155 \\
Level- Breitung\&Das (2005) & 0.8062 & 0.7519 & 6.8930 & 9.7906 & -0.1339 \\
Panel 3: Unit Root Test & -0.2568 & -1.5799 & 9.0501 & 12.4004 & 1.2231 \\
Level- IPS (2003) & -0.1958 & -0.6025 & -0.2515 & 2.1448 & 1.6438 \\
Panel 4: Unit Root Test & $-17.405^{* * *}$ & $-16.84^{* * *}$ & $-13.01^{* * *}$ & $-9.302^{* * *}$ & $-17.78^{* * *}$ \\
First Difference- & $-15.682^{* * *}$ & -18.5318 & $-12.60^{* * *}$ & $-9.651^{* * *}$ & $-16.77^{* * *}$ \\
$\begin{array}{l}\text { Breitung\&Das (2005) } \\
\text { Panel 5: Unit Root Test }\end{array}$ & $-29.568^{* * *}$ & $-12.239^{* * *}$ & $-11.01^{* * *}$ & $-9.51^{* * *}$ & $-18.30^{* * *}$ \\
$\begin{array}{l}\text { First Difference- } \\
\text { IPS (2003) }\end{array}$ & $-13.475^{* * *}$ & $-9.6414^{* * *}$ & $-9.211^{* * *}$ & $-9.21^{* * *}$ & $-21.23^{* * *}$ \\
\hline
\end{tabular}

Note: ${ }^{* *}, * *, *$ denotes signifance level at the $\% 1, \% 5, \% 10$ levels.

Table 4: Swamy-S Homogeneity Test

\begin{tabular}{|c|c|l|}
\hline Hypothesis & Statistics test & Probability \\
\hline$H_{0}: \beta_{i}=\beta$ & $\chi^{2}=41346.81$ & 0.0000 \\
\hline
\end{tabular}

Table 4 evidences that since the probability value is below 0.05 the null hypothesis was rejected and parameters were not homogeneous but heterogeneous, which means it changed from one unit to another.

It is known that when variables remain stationary at different levels we can expect to witness spurious regression. Since all the variables we examined in our research are first degree I (1), we had to find out if in the longterm they moved together, and to identify that, we employed the Pedroni (2004) and Gengenbach, Urbain and Westerlund (GUW) (2016) Panel Cointegration test to examine its long-term relationship. 
Table 5: Cointegration Tests Result

\begin{tabular}{|c|c|c|}
\hline \multicolumn{3}{|l|}{ Pedroni (2004) } \\
\hline Statistics & Panel & Group \\
\hline Panel v-statistic & -1.067 & \\
\hline$\rho$-statistic & $2.572 * *$ & $5.574 * * *$ \\
\hline Panel PP-statistic & $-5.042 * * *$ & $-6.089 * * *$ \\
\hline $\begin{array}{l}\text { Panel } \\
\text { statistic }\end{array}$ & $2.27 * * *$ & $3.37 * * *$ \\
\hline \multicolumn{3}{|c|}{$\begin{array}{l}\text { Gengenbach, Urbain ve Westerlund (GUW) } \\
\text { (2016) }\end{array}$} \\
\hline Coef. & T-bar & Prob. \\
\hline-1.247 & -10.322 & $<=0.01$ \\
\hline
\end{tabular}

Note: $* * *, * *, *$ denotes signifance level at the $\% 1, \% 5$, $\% 10$ levels.

The null hypothesis for the cointegration tests in Table 5 suggests that there is no cointegration. In the Pedroni test panel, $\mathrm{v}$ rho, $\mathrm{t}$ and adf statistics were selected according to lag length and the aic information criterion was computed. Within $95 \%$ confidence level $H_{0}$ was rejected for all statistics, meaning that among the variables there exists a cointegration relationship.

In the GUW (2016) test, the null hypothesis states that cointegration does not exist. In the GUW panel cointegration test, an analysis of $Y_{t-1}$ significance shows that since the $\mathrm{p}$-value $<=0.01$ the null hypothesis was rejected, hence it is detected that among variables a long-term relationship existed.

Table 6: FMOLS and DOLS Result Variables

\begin{tabular}{|c|c|c|c|c|c|c|}
\hline \multirow[t]{2}{*}{ Variables } & \multicolumn{2}{|l|}{ Model-I } & \multicolumn{2}{|l|}{ Model-II } & \multicolumn{2}{|l|}{ Model-III } \\
\hline & FMOLS & DOLS & FMOLS & DOLS & FMOLS & DOLS \\
\hline FD & $0.0996 * * *$ & $0.1197 * * *$ & $0.0878 * * *$ & $0.1322 * * *$ & $0.0916 * * *$ & $0.1260 * * *$ \\
\hline FD $^{2}$ & $-0.0737 * * *$ & $-0.0659 * * *$ & $-0.0567 * * *$ & $-0.0849 * * *$ & $-0.0529 * * *$ & $-0.0806 * * *$ \\
\hline InGDP & 0.00997 & $0.1392 * * *$ & $0.0139 * * *$ & $0.1550 * * *$ & 0.0121 & $0.1564 * * *$ \\
\hline $\operatorname{lnGDP}{ }^{2}$ & $-0.0192 * * *$ & $-0.0108 * * *$ & $-0.0180 * * *$ & $-0.0112 * * *$ & $-0.0150 * *$ & $-0.0113 * * *$ \\
\hline $\operatorname{lnGC}$ & & & $-0.0222 * * *$ & $-0.0398 * * *$ & $-0.0218 * * *$ & $-0.0416 * * *$ \\
\hline INF & & & & & $-0.0223 * *$ & $-0.0001 * *$ \\
\hline
\end{tabular}

Note: ${ }^{* *}, *^{* *}, *$ denotes signifance level at the $\% 1, \% 5, \% 10$ levels

Table 6 displays FMOLS (the Fully Modified Least Squares) and DOLS (Dynamic Least Squares) model estimations for three distinct models. To test the GJ (1990) hypothesis, in other words, to test the relationship between financial development and income, FD (financial development) and $\mathrm{FD}^{2}$ (square of FD) variables are as exhibited in Model 1. Coefficients of FD indicating linear term and $\mathrm{FD}^{2}$ variables indicating nonlinear terms are measured respectively as 0.0996 and -0.0737 . These significant variables escalated income inequality in the first stage of FD but in the next stage - that is when the finance sector reached certain maturity - FD would diminish income inequality. In Model 2 and Model 3 too, where control variables were integrated, identical results were obtained. Results collected from Models 1, 2 and 3 confirmed that between FD and income inequality an inverted $U$ relationship existed, and these findings are aligned with studies conducted by Clarke et al. (2003, 2007), Rehman et al. (2008), Batuo et al. (2010), Kim and Lin (2011), Rötheli (2011), Nikoloski (2012), Shahbaz et al. (2014), Koçak and Uzay (2019).

Kuznets' (1955) theory which explains the relationship between economic growth and income distribution suggests that at the start of economic growth it would moderately increase income inequality, but in the subsequent stages, it was reported that this situation would be reversed. To represent economic growth coefficients of the lnGDP variable indicating a 
linear term and the $\operatorname{lnGDP}{ }^{2}$ variable indicating a nonlinear term in DOLS, Model 1 was measured respectively as 0.1392 and -0.0108 in $1 \%$ significance level. These findings confirm Kuznets' inverted U-curve, meaning that in the first stage economic growth heightened income inequality, but in the following stages it decreased income inequality, and these results are in parallel with the findings obtained by Bittencourt et al. (2019).

In Model 2, government expenditures and in Model 3, the inflation variable was utilised as the control variable. Among these control variables, government expenditures were detected to be negative and significant. A rise in government expenditures is a factor lowering income inequality (see Models 2 and 3). These results are in parallel with Clarke et al. (2006).

Inflation has an inverted effect on income distribution and is significant at a 5\% level. If all variables are fixed, an increase by $1 \%$ in inflation decreased income inequality by a ratio of $0.02 \%$, and these findings are aligned with the research conducted by Shahbaz (2010), Shahbaz and İslam (2011), Bittencourt (2010), Shahbaz et al. (2015) and others.

\subsection{Method of Moments Quantile Regression}

The MMQR technique introduced by Machado and Silva (2019) differs from Shahbaz et al. (2014) and Canay (2011) because that model allows the presence of a unit effect, which is the location-fixed effect estimation of conditional quantiles by employing panel data. This method can offer insights into how explanatory variables can affect the entire conditional distribution. Also according to Machado and Silva (2019), when $\left\{\left(G_{i n i} i_{i t}, X_{i t}\right)^{\prime}\right\}$ is analysed as the data set, here Gini $i_{i t}$ indicates income inequality in $t$ time and $i$ country and $X_{i t}$ indicates explanatory variables such as FD, GDP, government expenditures and inflation. Gini's conditional quantile distribution estimation as location-scale form is:

$Y_{i t}=\alpha_{i}+X_{i t}^{\prime} \beta+\sigma\left(\delta+Z_{i t}^{\prime} \gamma\right) U_{i t}$
$P\left\{\delta_{i}+Z^{\prime}{ }_{i t} \gamma>0\right\}=1$ is expressed as a probability, where $\alpha, \delta, i=1,2, \ldots, n$ to $i$ catches fixed effects of the country, $Z$ indicates differentiable conversions of $X$ independent variable components, $\beta$ indicates one vector of estimation parameters of the equation changing according to different quantile $\tau$ slice of Gini.

$X_{i t}$ and $U_{i t}$, is distributed identically in $i$ country, $t$ time. According to Machado and Silva (2019) the standardised Moment condition is $U_{i t}$, and orthogonal to $X$, therefore Equation 1 can be simplified as below:

$$
\begin{gathered}
Q_{Y}\left(\tau \mid X_{i t}\right)=\left(\alpha_{i}+\delta_{i} q(\tau)\right)+X_{i t}^{\prime} \beta \\
+Z_{i t}^{\prime} \gamma q(\tau)
\end{gathered}
$$

In Equation 2 as $X_{i t}^{\prime}$ explanatory variable vector, financial development as (FD), the square of financial development $\mathrm{FD}^{2}$ economic growth (lnGDP), the square of economic growth $\left(\ln G D P^{2}\right)$, government expenditures (lnGC) and inflation variables. $Q_{Y}\left(\tau \mid X_{i t}\right)$ indicates quantile distribution of income inequality (Gini). $\alpha_{i}(\tau) \equiv \alpha_{i}+\delta_{i} q(\tau)$ scale coefficient as for $i$ country $\tau$. quantile fixed effect or distribution effect in $\tau$.

The distribution effect differs from the ordinary fixed effect since there exists no location shift in general. In short, the distribution effect indicates an effect that, like other variables, allows conditional distribution to have different effects in different regions of $Y$ and personal features that are not bound to change in due course. To make $\int_{0}^{1} q(\tau) d \tau=0$ it can be interpreted as the mean effect of $\alpha_{i}$ for $i$ country.

Machado and Silva (2019) express this optimisation as:

$$
{ }_{q}^{\min } \sum_{i} \sum_{t} \rho_{\tau}\left(\hat{R}_{i t}-\left(\hat{\delta}_{i}+Z_{i t}^{\prime} \gamma\right) q\right)
$$

Where $\rho_{\tau}(A)=(\tau-1) A I\{A \leq 0\}+\tau A I(A \geq$ $0)$ is the control function. 
İzmir İktisat Dergisi (İzmir Journal of Economics) , Yıl:2021, Cilt:36, Sayı:3, ss. 725-737

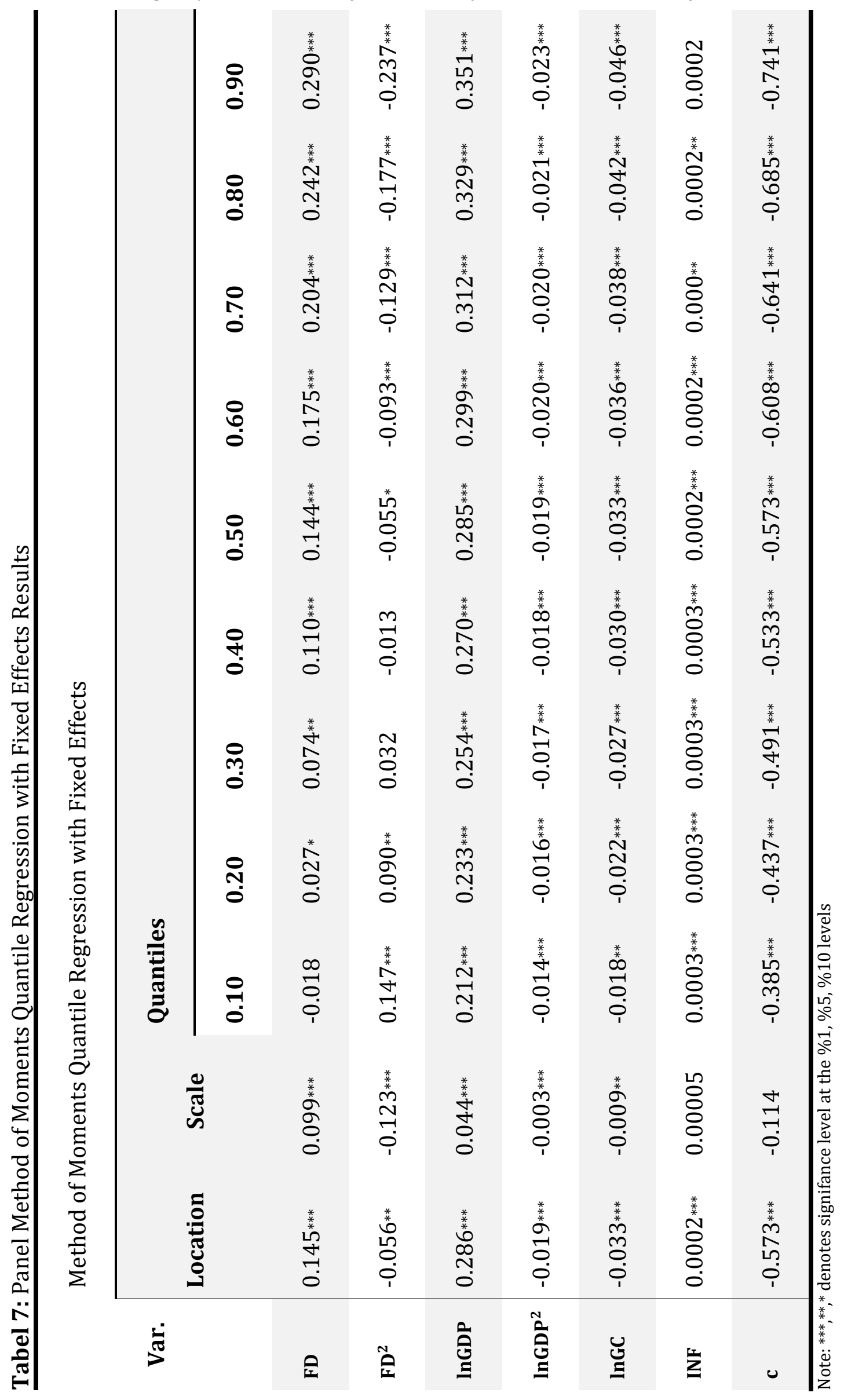


Quantile Regression results in Table 7 show that in the first stage FD has a statistically significant and negative effect on income distribution, meaning that a greater FD would result in a less equal income distribution. In this stage FD lowers income inequality in all quantile levels, and as inequality increases its effect also increases.

In the second stage of FD, after the median (from 0.4 to 0.9 ) income, it has a statistically significant and positive effect on distribution, meaning that a greater FD would result in a more equal income distribution.

In countries with more unequal income distribution FD lowers income inequality after the 0.4 th quantile, while in countries with more equal income distribution within the 0.10th and 0.20th quantiles income inequality is elevated. As can be construed from this relation, in the second stage of FD, Galor and Zeira's (1990) hypothesis is confirmed and this result is also in parallel with DOLS and FMOLS findings. Nevertheless, for countries having more equal income distribution (for the quantiles after median) income inequality supports the widening hypothesis and these results are in parallel with the research of Nikoloski (2012).

In expressing economic growth lnGDP that indicates linear term increases income inequality in all quantile levels, and as inequality increases its effect also rises. Indicating nonlinear terms, $\operatorname{lnGDP}{ }^{2}$ increases income inequality in all quantile levels, and as inequality increases its effect also rises, and this result is consistent with FMOLS and DOLS results and aligns with the study of Bittencourt et al. (2019).

Government expenditure diminishes income inequality in all quantile levels and inequality increases its effect. The results of FMOLS and DOLS are also similar and these results are consistent with the study of Clarke et al. (2006).

The effect of inflation on income distribution appears to be significant from the 0.10th quantile to the 0.80th quantile. In panel quantile estimation results, when inflation coefficients are compared with FMOLS and DOLS, although the coefficient signal direction is similar, the effect is weaker.
Inflation increases income inequality in all quantile levels and the results of FMOLS and DOLS are also supportive of this statement. These findings are in line with not only the results of FMOLS and DOLS but also with the studies of Shahbaz (2010), Shahbaz and İslam (2011), Bittencourt (2010), Shahbaz et al. (2015) and others.

\section{CONCLUSION}

In this research, linear and nonlinear relationships of FD and effects on the income inequality of 79 countries for the period between 1995-2006 were examined. For the analysis the Gini coefficient, FD, square of FD, square $\operatorname{lnGDP}$ and $\operatorname{lnGDP}$ as well as inflation and government expenditure as control variable were employed. Since all series were stationary in I(1) they were tested via unit root tests. Among these series, the cointegration relationship was examined and a long-term relationship was then identified among the series. Via FMOLS and DOLS, coefficients were estimated and also the MMQR technique, which allows different effects of exogenous variables in the different quantiles of conditional distribution of income inequality, was employed in the study.

FMOLS and DOLS coefficient estimations put forth that in the first stage FD would escalate income inequality, but after a specific maturity level it would lower income inequality, and it was also ascertained that in the first stage economic growth would enhance income inequality but in the second stage it would shrink inequality. FMOLS and DOLS results are supportive of the Kuznets (1955) and Greenwood and Jovanovic (1990) hypotheses.

In the first stage of FD, MMQR results result in greater FD, therefore a more unequal income distribution. In this stage, FD lowered income inequality in all quantile levels but as inequality increased, its effect also rose. As FD reaches a certain maturity in countries where income inequality is disrupted, FD between the 0.4 and 0.9 quantiles can lead to more equal income distribution. For such countries with greater income inequality the Galor and Zeira (1990) 
hypothesis is confirmed, but in countries with more equal income distribution, this hypothesis is found to be invalid. For these countries the widening hypothesis of income inequality is supported, and these findings are compatible with Nikoloski (2012).

In the depiction of economic growth, lnGDP indicating linear terms escalated income inequality in all quantile levels, and as inequality increased the effect also rose. $\operatorname{lnGDP}{ }^{2}$ indicating nonlinear terms decreased inequality in all quantile levels, and as inequality increased the effect also rose. This finding is consistent with FMOLS and DOLS results and also aligned with the study by Bittencourt et al. (2019). Inflation and government expenditures diminished income inequality in all quantile levels (countries with equal or not equal distribution of income) and as inequality increased, its effect also moved upwards.

\section{REFERENCES}

Alhassan, A., Usman, O., Ike, G. N., Sarkodie, S. A. (2020). Impact assessment of trade on environmental performance: accounting for the role of government integrity and economic development in 79 countries. Heliyon, 6(9), e05046.

Altunbaş, Y., Thornton, J. (2018). The impact of financial development on income inequality: A quantile regression approach. Economics Letters, 175, 51-56.

Banerjee, A. V., Newman, A. F. (1993). Occupational choice and the process of development. Journal of political economy, 101(2), 274-298.

Batuo, M. E., Guidi, F., Mlambo, K. (2010). Financial development and income inequality: Evidence from African Countries. African Development Bank, 44, 1-27.

Beck, T., Demirguc-Kunt, A., Levine, R. (2004). Finance, inequality, and poverty: Cross-country evidence (No. w10979). National Bureau of Economic Research.

Bittencourt, M., Chang, S., Gupta, R., Miller, S. M. (2019). Does financial development affect income inequality in the US States? Journal of Policy Modeling, 41(6), 1043-1056.

Breitung, J., Das, S., 2005. Panel unit root tests under cross-sectional dependence. Statistica Neerlandica, 59(4), 414-433.
Canay, I. A. (2011). A simple approach to quantile regression for panel data. The Econometrics Journal, 14(3), 368-386.

Chakroun, M. (2019). Threshold effects in the relationship between financial development and income inequality. International Journal of Finance \& Economics, 25(3), 365-387.

Clarke, G. R., Zou, H. F., Xu, L. C. (2003). Finance and income inequality: test of alternative theories (Vol. 2984). World Bank Publications.

Clarke, G. R., Xu, L. C., Zou, H. F. (2006). Finance and income inequality: what do the data tell us? Southern economic journal, 578-596.

De Haan, J., Sturm, J. E. (2017). Finance and income inequality: A review and new evidence. European Journal of Political Economy, 50, 171-195.

Demirgüç-Kunt, A., Levine, R. (2009). Finance and inequality: Theory and evidence. Annu. Rev. Financ. Econ., 1(1), 287-318.

Galor, O., Zeira, J. (1993). Income distribution and macroeconomics. The review of economic studies, 60(1), 35-52.

Gengenbach, C., Urbain, J. P., Westerlund, J. (2016). Error correction testing in panels with common stochastic trends. Journal of Applied Econometrics, 31(6), 982-1004.

Greenwood, J., Jovanovic, B. (1990). Financial development, growth, and the distribution of income. Journal of political Economy, 98(5, Part 1), 1076-1107. 
Im, K. S., Pesaran, M. H., Shin, Y. (2003). Testing for unit roots in heterogeneous panels. Journal of econometrics, 115(1), 53-74.

Jauch, S., Watzka, S. (2015). Financial development and income inequality: a panel data approach. Empirical Economics, 51(1), 291-314.

Kaidi, N., Mensi, S., Amor, M. B. (2019). Financial development, institutional quality and poverty reduction: worldwide evidence. Social Indicators Research, 141(1), 131-156.

Kim, D. H., Lin, S. C. (2011). Nonlinearity in the financial development-income inequality nexus. Journal of Comparative Economics, 39(3), 310-325.

Koçak, E., Uzay, N. (2019). The effect of financial development on income inequality in Turkey: An estimate of the GreenwoodJovanovic hypothesis. Review of Economic Perspectives, 19(4), 319-344.

Kuznets, S. (1955). Economic growth and income inequality. The American economic review, 45(1), 1-28.

Levine, R. (2005). Finance and growth: theory and evidence. Handbook of economic growth, 1, 865-934.

Liang, Z. (2008). Financial development and income inequality in rural China 1991-2000. In Understanding Inequality and Poverty in China (pp. 72-88). Palgrave Macmillan, London.

Machado, J. A., Silva, J. S. (2019). Quantiles via moments. Journal of Econometrics, 213(1), 145-173.

Nasreddine, K., Mensi, S. (2016). Financial development and income inequality: The linear versus the nonlinear hypothesis. Economics Bulletin, 36(2), 609626.

Nikoloski, Z. (2012). Financial sector development and inequality: is there a financial Kuznets curve? Journal of International Development, 25(7), 897-911.
Pesaran, M. H. (2004). General diagnostic tests for cross-sectional dependence in panels. Empirical Economics, 1-38.

Rehman, H. U., Khan, S., Ahmed, I. (2008). Income distribution, growth and financial development: A cross countries analysis. Pakistan Economic and Social Review, 1-16.

Rötheli, T. F. (2011). The Kuznets curve: determinants of its shape and the role of finance. Studies in Economics and Finance.

Satti, S. L., Mahalik, M. K., Shahbaz, M. (2015). Dynamics of income inequality, finance and trade in Kazakhstan: Empirical evidence from a new transition economy with policy prescriptions. Monash Univ., Department of Economics.

Sethi, P., Bhattacharjee, S., Chakrabarti, D., Tiwari, C. (2021). The impact of globalization and financial development on India's income inequality. Journal of Policy Modeling.

Shahbaz, M. (2010). Income inequalityeconomic growth and non-linearity: A case of Pakistan. International Journal of Social Economics.

Shahbaz, M., Islam, F. (2011). Financial development and income inequality in Pakistan: an application of ARDL approach.

Shahbaz, M., Loganathan, N., Tiwari, A. K., Sherafatian-Jahromi, R. (2014). Financial development and income inequality: Is there any financial Kuznets curve in Iran? Social Indicators Research, 124(2), 357-382.

Shin, H., Lee, K. (2019). Impact of financialization and financial development on inequality: Panel cointegration results using OECD data. Asian Economic Papers, 18(1), 6990.

Thornton, J., Di Tommaso, C. (2019). The longrun relationship between finance and income inequality: Evidence from panel data. Finance Research Letters, 32, 101180.

Topuz, A. G. D. S. G., Dağdemir, Ö. (2016). Financial development and the income 
İzmir İktisat Dergisi (İzmir Journal of Economics) , Yll:2021, Cilt:36, Sayı:3, ss. 725-737

inequality: a panel data analysis. Anadolu University Journal of Social Sciences, 16(3), 1934.

Younsi, M., Bechtini, M. (2018). Economic Growth, Financial Development and Income Inequality in BRICS Countries: Evidence from Panel Granger Causality Tests. 